\title{
Genetic diversity analysis of daluga (Cyrtosperma merkusii) using Sequence-Related Amplified Polymorphism in Siau, Sangihe and Talaud Islands, North Sulawesi, Indonesia
}

\author{
INA ERLINAWATI ${ }^{1,2, \boldsymbol{v}}$, ABINAWANTO ${ }^{1, v \vee}$, ANDI SALAMAH $^{\mathbf{1}}$, RUGAYAH $^{2}$ \\ ${ }^{1}$ Department of Biology, Faculty of Mathematics and Natural Sciences, Universitas Indonesia. Kampus UI Gedung E Level 2, Jl. Lingkar Kampus Raya, \\ Pondok Cina, Beji, Depok 16424, West Java, Indonesia. Tel./Fax.+62-21-7270163, ^^email: abinawanto.ms@sci.ui.ac.id, abinawanto@gmail.com. \\ ${ }^{2}$ Herbarium Bogoriense, Botany Division, Research Center for Biologi, Indonesian Institut of Sciences. Cibinong Science Centre, Jl. Raya Jakarta-Bogor \\ Km. 46, Cibinong, Bogor 16911, West Java, Indonesia. Tel.: +62-21-765066, Fax.: +62-21-8765062, "email: inaerlinawati@gmail.com, \\ ina_erlinawati@yahoo.com.
}

Manuscript received: 9 September 2018. Revision accepted: 23 November 2018.

\begin{abstract}
Erlinawati I, Abinawanto, Salamah A, Rugayah. 2018. Genetic diversity analysis of daluga (Cyrtosperma merkusii) using Sequence-Related Amplified Polymorphism in Siau, Sangihe and Talaud Islands, North Sulawesi, Indonesia. Biodiversitas 19: 23742380. Daluga or the giant swamp taro (Cyrtosperma merkusii (Hassk.) Schott, a member of Araceae, is one of the minor tuber crops in Indonesia. It has high nutritional value for alternative food. Sequences-Related Amplified Polymorphism (SRAP) primers combinations were used for the first time to assess the genetic diversity among 36 of daluga accessions from several locations in Siau, Sangihe and Talaud islands, North Sulawesi, Indonesia. All of the samples were successfully extracted from silica-gel dried leaves using CTAB methods with minor modifications. Using six SRAP primer combinations, a total of 80 DNA fragments were yielded, varied from 75$1500 \mathrm{bp}$. The scoring of the fragments resulted in $68(85.03 \%)$ polymorphic bands. Amongst four populations studied, Siau Island population has the highest level of genetic variation with mean values of $\mathrm{Na}=1.9375 \pm 0.2436, \mathrm{Ne}=1.6409 \pm 0.3255, \mathrm{PPL}=93.75 \%, \mathrm{H}$ $=0.3614 \pm 0.1516$ and $\mathrm{I}=0.5299 \pm 0.1978$. Meanwhile, Salibabu, Talaud Island population has the lowest level of genetic variation with mean values of $\mathrm{Na}=1.5125 \pm 0.5030, \mathrm{Ne}=1.3075 \pm 0.3723, \mathrm{PPL}=51.25 \%, \mathrm{H}=0.1800 \pm 0.1989$ and $\mathrm{I}=0.2700 \pm 0.2855$. The high of polymorphic bands were generated by SRAP markers suitable for further analysis method in applied and basic of the genetic study on Cyrtosperma species and also related genera. This new genetic information can be used for baseline data for further research especially to improving the variation of daluga and for the conservation of daluga in the future.
\end{abstract}

Keywords: Cyrtosperma merkusii, daluga, genetic diversity, SRAP.

\section{INTRODUCTION}

Cyrtosperma merkusii (Hassk.) Schott, which is called daluga in Sulawesi or giant swamp taro, is one of the important food belongs to aroid family (Araceae) which has not been cultivated in Indonesia. C. merkusii is an interesting crop which has received too little scientific attention. Daluga can produce food under conditions where other crops fail such as the conditions of drought, floods, fresh, and brackish water swamps. This ability makes daluga become a very useful plant in Oceania (Evangelio 1996). This species also become a major crop in the Pacific (Rao et al. 2014). Many uses are reported for this species, such as the leaves are eaten for vegetables and also used as a food wrapper (Plucknett 1977; Manner 2011). Daluga also has been used in traditional medicine, such as in Karibiti, specialist used a yellow mold from sliced and sundried corms to treat skin infections. The tubers are eaten after boiling, steaming or roasting, and they can be preserved by peeling, slicing, scalding and drying in the sun for future use. Starch and flour also can be produced from these tubers (Manner 2011). In Siau, Sangihe and Talaud islands, people sometimes boiled daluga tuber and sometimes mixed with palm sugar, coconut, and water. In Sangihe Island, people also made a traditional cuisine namely "ketang-ketang" where the tuber of daluga coarse grated or thinly sliced and then fried with coconut oil, mixed with melted palm sugar and formed round like balls (pers.comm.).

Dingan et al. (1994) stated that per $100 \mathrm{~g}$ edible portion of the raw tuber of daluga contains $75 \mathrm{~g}$ of water, $308 \mathrm{kcal}$ $(75 \mathrm{~kJ})$ of energy, $0.5 \mathrm{~g}$ of protein, $0.2 \mathrm{~g}$ of total fat, $18 \mathrm{~g}$ of available carbohydrates, $2.8 \mathrm{~g}$ of dietary fibre, $72 \mathrm{mg}$ of sodium, $67 \mathrm{mg}$ of potassium, $182 \mathrm{mg}$ of calcium, $21 \mathrm{mg}$ of magnesium, $0.6 \mathrm{mg}$ of iron, $2.1 \mathrm{mg}$ of zinc, equivalent $5 \mu \mathrm{g}$ of total vitamin $\mathrm{A}$, equivalent $30 \mu \mathrm{g}$ of $\beta$-carotene, $0.03 \mathrm{mg}$ of thiamine, $0.02 \mathrm{mg}$ of riboflavin, $15.7 \mathrm{mg}$ of vitamin $\mathrm{C}$ and $2 \mathrm{mg}$ of vitamin $\mathrm{E}$. The high nutritional value for this species make daluga is potential to be developed as an alternative food to ensure food security, especially in small islands in Indonesia.

Study on daluga in Indonesia is still limited. The morphological studies have been conducted by Julianti et al. (2012) in Sangihe Island and Erlinawati et al. (2018) in Siau, Sangihe and Talaud Islands. The genetic variation of daluga has been studied by Julianti et al. (2015) which only restricted in Sangihe Island and concluded that DNA barcoding of daluga from Sangihe based on the matK gene could not distinguish variations intraspecies.

Molecular markers based on DNA are stable, detectable 
in all tissues and independent of environmental or seasonal conditions. They can be used for cultivar identification, diversity analysis, assessment of parentage, patent issues and quality control of rootstock-seed lots (Ahmad et al. 2004). A variety of molecular techniques have been developed for measuring genetic variability, such as RAPD (Random Amplified Polymorphic DNA), AFLP (Amplification Fragment Length Polymorphism), RFLP (Restriction Fragment Length Polymorphism), SNP (Single Nucleotide Polymorphism), SSR (Simple Sequence Repeats), ISSR (Inter Simple Sequence Repeats), and SRAP (Sequences Related Amplified Polymorphism). According to Ahmad et al. (2004), RAPD markers have poor reproducibility and low multiplexing output limit their use. AFLP markers have a multiplexing ratio, but their main disadvantage is the complexity and requirement of licensing for commercial purposes. SSR markers have disadvantages in time consuming and expensive for the developmental cost. Meanwhile, RFLP and NSP markers have disadvantages in high running cost.

One of the most reliable PCR based molecular marker systems is SRAP. SRAP is a novel marker which preferentially amplifier ORFs (Open Reading Frames) and combines simplicity, reliability, moderate multiplexing ability and facile sequencing of selected bands ( $\mathrm{Li}$ and Quiros 2001; Ahmad et al. 2004). SRAP is a PCR-based marker system that uses two primers. The first type of primer is called forward with $17 \mathrm{bp}$ long and contains fixed sequences of 14 nucleotides which rich in $\mathrm{C}$ and $\mathrm{G}$ contents and three selected bases at the 3' end. This primer preferentially amplifies exonic regions, which tend to be rich in these nucleotides. The second ones is called reverse with 18 bp long and contains sequences of 15 nucleotides, rich in A and T and three selected bases at the 3' end. This primer preferentially amplifies intronic regions with promoters, rich in these nucleotides. The observed polymorphism fundamentally originates in the variation of the length of these introns, promoters, and spacers, both among individuals and among species ( $\mathrm{Li}$ and Quiros 2001).

The SRAP marker system was developed primarily for Brassica species, but also tested in other crops such as potato, rice, apple, citrus, cherry, plum, garlic, lettuce and celery ( $\mathrm{Li}$ and Quiros 2001). According to Ahmad et al. (2004), SRAP markers appears to be much more effective, quicker and less expensive than are SSR markers in peach and nectarine cultivars. SRAP markers is also a useful DNA fingerprinting tool for evaluation of genetic diversity of species, cultivars and breeding line such as in cumin (Amar et al. 2011; Bhatt et al. 2017), Vigna radiata (Aneja et al. 2013), tuber crop Dioscorea spp. (Wu et al. 2014), and Bouea macrophylla accessions (Kaewpongumpai et al. 2016).

The genetic diversity of daluga in Siau and Talaud has not been reported before. In our study, SRAP markers were used for the first time to analyze genetic diversity on giant swamp taro (daluga) so the objective of recent research was to determine genetic diversity among daluga in Siau, Sangihe and Talaud Islands (Karakelang and Salibabu), North Sulawesi using SRAP.

\section{MATERIALS AND METHODS}

\section{Study area and plant materials}

Thirty six of daluga accessions were collected on 28 April 2017-18 Mei 2017 from different sites in Siau, Sangihe and Talaud Islands, North Sulawesi (Table 1, Figure 1). Talaud Islands in this study consisted of Salibabu and Karakelang Islands.

The microclimate measurement indicated that daluga in Siau Island grew at 104-207 $\mathrm{m}$ above sea level (asl.), temperature $30-32^{0} \mathrm{C}$, air humidity $30-35 \%$, soil humidity $20-30 \%$ and $\mathrm{pH} 6.8-7$, whereas in Sangihe island, daluga grew at $7-143 \mathrm{~m}$ asl., temperature $31-36^{\circ} \mathrm{C}$, air humidity 48-51\%, soil humidity $20-50 \%$, and $\mathrm{pH}$ 6.2-7. Meanwhile in Talaud islands, daluga grew at 7-61 m asl., temperature $29-35^{\circ} \mathrm{C}$, air humidity $60-73 \%$, soil humidity $30-50 \%$, and pH 6.6-7 (Erlinawati et al. 2018).

Table 1. Accessions of daluga from Siau, Sangihe and Talaud (Salibabu and Karakelang) Islands, North Sulawesi, Indonesia

\begin{tabular}{|c|c|c|}
\hline $\begin{array}{l}\text { Population no./ } \\
\text { accessions no. }\end{array}$ & Population & $\begin{array}{l}\text { Accession } \\
\text { no. }\end{array}$ \\
\hline $1 / 1$ & Balirangin, Siau & IE 548a \\
\hline $1 / 2$ & Balirangin, Siau & IE $548 b$ \\
\hline $1 / 3$ & Balirangin, Siau & IE 548c \\
\hline $1 / 4$ & Balirangin, Siau & IE 549 \\
\hline $1 / 5$ & Tanaki, Siau & IE 550 \\
\hline $1 / 6$ & Tanaki, Siau & IE 551 \\
\hline $1 / 7$ & Tanaki, Siau & IE 552 \\
\hline $1 / 8$ & Tanaki, Siau & IE 553 \\
\hline $1 / 9$ & Tanaki, Siau & IE 554 \\
\hline $1 / 10$ & Dusun Tiga, Siau & IE 555 \\
\hline $1 / 11$ & Dusun Tiga, Siau & IE 556 \\
\hline Total of accessions & & 11 \\
\hline $2 / 12$ & Lelipambeh, Sangihe & IE 564 \\
\hline $2 / 13$ & Balaneh, Sangihe & IE $565 \mathrm{a}$ \\
\hline $2 / 14$ & Balaneh, Sangihe & IE $565 b$ \\
\hline $2 / 15$ & Balaneh, Sangihe & IE $565 \mathrm{c}$ \\
\hline $2 / 16$ & Hesang, Sangihe & IE 567 \\
\hline $2 / 17$ & Hesang, Sangihe & IE 568 \\
\hline $2 / 18$ & Hesang, Sangihe & IE 569 \\
\hline $2 / 19$ & Hesang, Sangihe & IE 570 \\
\hline $2 / 20$ & Mahena, Sangihe & IE 571 \\
\hline $2 / 21$ & Mahena, Sangihe & IE 572 \\
\hline $2 / 22$ & Naha, Sangihe & IE 575 \\
\hline $2 / 23$ & Naha, Sangihe & IE 576 \\
\hline Total of accessions & & 12 \\
\hline $3 / 24$ & Bantik, Karakelang & IE 577 \\
\hline $3 / 25$ & Bantik, Karakelang & IE 578 \\
\hline $3 / 26$ & Bantik, Karakelang & IE 579 \\
\hline $3 / 27$ & Niyampak, Karakelang & IE $580 \mathrm{a}$ \\
\hline $3 / 28$ & Niyampak, Karakelang & IE $580 \mathrm{~b}$ \\
\hline $3 / 29$ & Niyampak, Karakelang & IE $580 \mathrm{c}$ \\
\hline $3 / 30$ & Niyampak, Karakelang & IE 586 \\
\hline Total of accessions & & 7 \\
\hline $4 / 31$ & Musi, Salibabu & IE 587 \\
\hline $4 / 32$ & Pertamina Camp, Salibabu & IE 588 \\
\hline $4 / 33$ & Pertamina Camp, Salibabu & IE 589 \\
\hline $4 / 34$ & Moronge, Salibabu & IE 590 \\
\hline $4 / 35$ & Moronge, Salibabu & IE 591 \\
\hline $4 / 36$ & Ds. Salibabu, Salibabu & IE 594 \\
\hline Total of accessions & & 6 \\
\hline Total of all accessions & & 36 \\
\hline
\end{tabular}




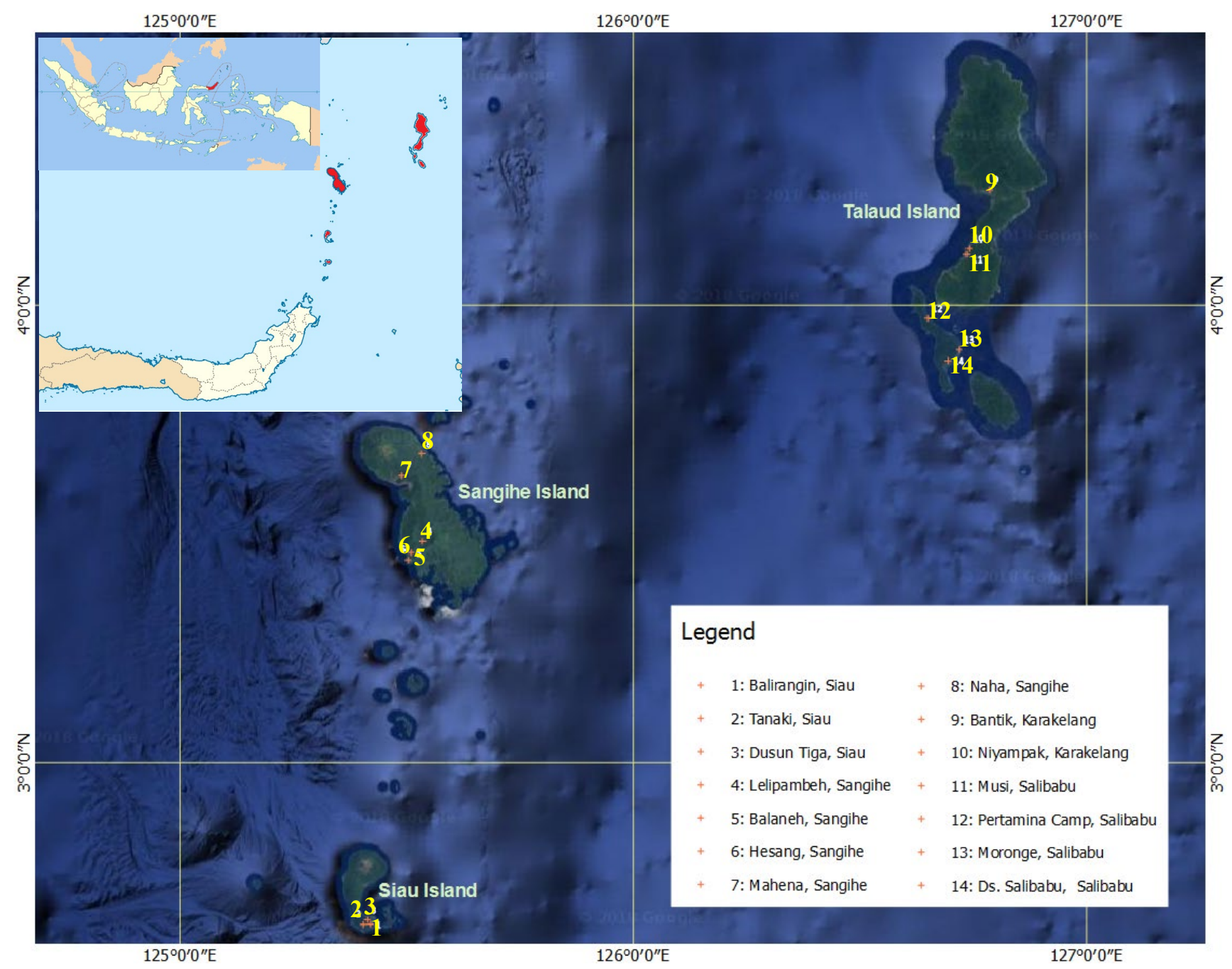

Figure 1. Sampling sites of daluga in Siau, Sangihe and Talaud (Salibabu and Karakelang) Islands, North Sulawesi, Indonesia

The molecular work was conducted in Molecular Systematic Laboratory, Botany Division, Research Center for Biology, Indonesian Institute of Sciences on 13 December 2017-19 April 2018.

\section{Procedures}

\section{DNA extraction and amplification}

Total DNA was extracted from silica-gel dried leaves by minor modification of CTAB method (Doyle and Doyle 1987; Ardiyani et al. 2014). DNA quality and quantity were determined on $1 \%$ agarose gel. Primers pairs used in this study were synthesized by Ward Medic Ltd., Part. Thailand (Table 2). Firstly, eight SRAP primer combinations were screened in three representative samples (IE 548a, IE 554, and IE 555). Under the optimized condition, six primer combinations, generated strong and clear amplified bands, were selected for further investigations.

The primers pair combinations were me $1 \mathrm{~F}+\mathrm{em} 2 \mathrm{R}$, me $2 \mathrm{~F}+\mathrm{em} 2 \mathrm{R}, \mathrm{me} 3 \mathrm{~F}+\mathrm{em} 2 \mathrm{R}, \mathrm{me} 2 \mathrm{~F}+\mathrm{em} 3 \mathrm{R}, \mathrm{me} 3 \mathrm{~F}+\mathrm{em} 3 \mathrm{R}$, and me4F+em2R. The PCR was performed using a TaKaRa PCR Thermal Cycler. The PCR reaction mixtures with total volumes $15 \mu \mathrm{L}$ consisted of $1 \mu \mathrm{L}$ template DNA, $7.8 \mu \mathrm{L} \mathrm{Gmm}, 5.4 \mu \mathrm{L} \mathrm{dH_{2 }} \mathrm{O}$, and $0.4 \mu \mathrm{L}$ of each primer. The SRAP amplification process was started with heat shock at $94^{\circ} \mathrm{C}$ for 5 minutes then DNA was denaturized at $94^{\circ} \mathrm{C}$ for 1 minute, annealing at $35^{\circ} \mathrm{C}$ for 1 minute and DNA extension was done at $72^{\circ} \mathrm{C}$ for 1 minute for the first 5 cycles and followed by 35 cycles of 1 minute at $94^{\circ} \mathrm{C}$ (denaturation), 1 minute at $50^{\circ} \mathrm{C}$ (annealing) and 1 minute at $72^{\circ} \mathrm{C}$ (extension) ( $\mathrm{Li}$ et al. 2013; Bhatt et al. 2017). The final extension was performed at $72^{\circ} \mathrm{C}$ for 8 minutes. After 35 cycles, the profile was linked on hold at $25^{\circ} \mathrm{C}$. The PCR reactions were repeated twice for each primer pair to ensure reproducibility.

Table 2. Sequences of SRAP forward and reverse primers.

\begin{tabular}{lll}
\hline Primer code & Type & Sequences 5'-3, \\
\hline me1 & Forward & TGA GTC CAA ACC GGA TA \\
me2 & Forward & TGA GTC CAA ACC GGA GC \\
me3 & Forward & TGA GTC CAA ACC GGA AT \\
me4 & Forward & TGA GTC CAA ACC GGA CC \\
em2 & Reverse & GAC TGC GTA CGA ATT TGC \\
em 3 & Reverse & GAC TGC GTA CGA ATT GAC \\
\hline
\end{tabular}




\section{Data analysis}

The SRAP products were analyzed using $1.5 \%$ agarose gel in $160 \mathrm{~mL}$ TBE and stained with $8 \mu \mathrm{L}$ gel red. The gels were viewed and photographed using a Gel Documentation System (Bioinstrument-Atto). The size of each DNA band was inferred by comparison with a 100 bp DNA ladder (Promega) to determine SRAP profiles. The amplified products of SRAP markers (Fig. 1) were scored as 1 and 0 , where $1=$ presence of band and $0=$ absence of band. Genetic similarity between genotypes was calculated by SimQual program with distance coefficient and Unweighted Pair Group Method Average (UPGMA) dendrogram was constructed using SAHN clustering algorithm in NTSYSpc.v.2.20 (Rohlf 2005).

\section{RESULTS AND DISCUSSION}

Daluga (Cyrtosperma merkusii) is very potential to be one of an alternative food to ensure food security in Indonesia, particularly in small islands, such as Siau, Sangihe, Talaud (Karakelang and Salibabu) Islands (Erlinawati et al. 2018). A series of researches need to be done. The genetic diversity analysis is necessary in plant breeding, plant systematics, and evolution also in plant pathology ( $\mathrm{Li}$ et al. 2013). Genetic variability on daluga has been previously studied using different molecular marker by Julianti et al. (2015), but they concluded that DNA barcoding of daluga from Sangihe based on the matK gene could not distinguish variations intraspecies. The Sequence-Related Amplified Polymorphism (SRAP) is the new marker technique based on PCR. This study is the first application of SRAP markers as a technique for estimating genetic diversity on daluga in Siau, Sangihe, Talaud (Karakelang and Salibabu) Islands.

\section{Polymorphism and primer evaluation}

The six primer combinations of Sequence-Related Amplified Polymorphism (SRAP) were used on daluga from Siau, Sangihe and Talaud Islands resulted PCR product that can be read and scored for further analysis. The primer combinations and total bands product which are yielded were shown in Table 3. A representative of the molecular profile of daluga generated with one of SRAP combination primer $(\mathrm{me} 3 \mathrm{~F}+\mathrm{em} 3 \mathrm{R})$ were performed in Figure 2.

Analysis of genetic diversity using six SRAP primer combinations on 36 accessions of daluga from 4 wild populations generated a total of 80 bands, of which 68 $(85.03 \%)$ were polymorphic bands. The number of polymorphic bands varied from 7 in primer combination $\mathrm{me} 4 \mathrm{~F}+\mathrm{em} 2 \mathrm{R}$ to 15 in primer combination me3F+em $2 \mathrm{R}$ with the average of polymorphic bands were 11.33. The size of amplified bands ranged from 75-1500 bp (Table 3).

This result indicated that SRAP marker has a high level of polymorphism with more than $50 \%$ bands are polymorphic bands, therefore, SRAPs can supply rich genetic information for daluga and are a suitable method since it is an efficient, low cost, simple, and reliable method for molecular analysis to evaluate the genetic diversity. The extent polymorphism is important to identify accurate associations among accessions (Bhatt et al. 2017). The level of polymorphism was comparatively higher than previous studies on many crops such as in Pinus, the level of polymorphism is 55\% (Feng et al. 2009) and 57.27\% in Bouea macrophylla (Kaewpongumpai et al. 2016).

Table 3. Features of SRAP amplified products used for analysis of genetic diversity of daluga

\begin{tabular}{lcccc}
\hline $\begin{array}{c}\text { Primer } \\
\text { combinations }\end{array}$ & $\begin{array}{c}\text { Band size } \\
\text { (base } \\
\text { pairs) }\end{array}$ & $\begin{array}{c}\text { Total } \\
\text { bands }\end{array}$ & $\begin{array}{c}\text { Poly- } \\
\text { morphic } \\
\text { bands }\end{array}$ & $\begin{array}{c}\% \text { Poly- } \\
\text { morphism }\end{array}$ \\
\hline me1F+em2R & $100-1500$ & 12 & 10 & 83.33 \\
me2F+em2R & $75-1500$ & 12 & 11 & 91.67 \\
me2F+em3R & $80-1500$ & 13 & 12 & 92.31 \\
me3F+em2R & $100-1500$ & 15 & 15 & 100 \\
me3F+em3R & $100-1500$ & 14 & 13 & 92.86 \\
me4F+em2R & $75-1500$ & 14 & 7 & 50.00 \\
Total & $75-1500$ & 80 & 68 & \\
Mean & & 13.33 & 11.33 & 85.03 \\
\hline
\end{tabular}

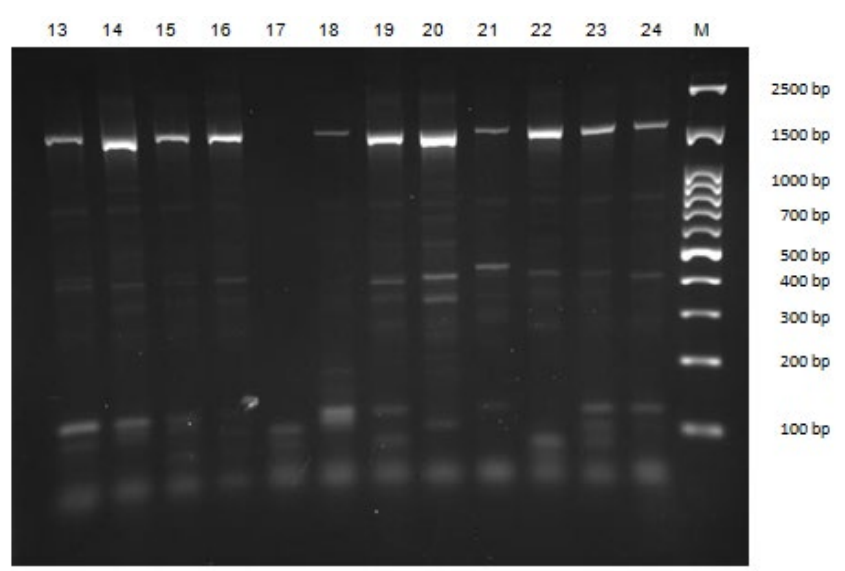

Figure 2. An example of the molecular profile of daluga generated with SRAP combination primer me3F + em $3 R$. Notes: $1=$ IE565b, $2=$ IE 565c, 3=IE 566, 4= IE567, 5= IE 568, 6= IE569, 7= IE570, 8= IE571, 9= IE572, 10= IE575, 11= IE576, 12=IE577, 13=IE 578, 14=IE579, 15=IE580a, 16=IE580b, 17=IE580c, 18=IE586, 19=IE587, 20=IE588, 21=IE589, 22=IE590, 23=IE591, 24=IE 598, and M = DNA marker (100 bp ladder Promega) 


\section{Cluster analysis}

The UPGMA cluster analysis from 36 accessions of daluga based on the SRAP data showed separation of accessions into two major clusters, cluster A with similarity coefficient value is 0.65 and cluster $B$ with similarity coefficient value is 0.54 (Figure 3 ). This clustering in line with morphological studied was done by Erlinawati et al. (2018) that grouped daluga based on the length of peduncle. Cluster A consisted of all accessions with long peduncle $(>1 \mathrm{~m})$, whereas cluster B consisted of 25 accessions with short peduncle $(\leq 1 \mathrm{~m})$ except 3 accessions with long peduncle (IE 566, IE 568 and IE 569). This result needs further analysis by combining the morphology and molecular data.

Most of the accessions are grouped based on their provenances, but some of the accessions are grouped randomly. Cluster A comprising two subcluster (E and F) which are consisted of accessions from Siau and only one accession from Sangihe (IE 565a). Cluster B comprising two subcluster (C and D). Subcluster C consisted of rest accessions from Siau and only one accession from Karakelang, Talaud (IE 580c). Subcluster D consisted of two sub subcluster ( I and J) and consisted of several small groups, where the majority are grouped based on their provenance $(\mathrm{K}$ and $\mathrm{N})$, and cluster randomly ( $\mathrm{L}$ and $\mathrm{M}$ ). Subcluster K consisted of IE 578, IE 579, IE 580a, and IE 580 b from Karakelang, Talaud Islands. Subcluster N consisted of IE 589, IE 590, IE 591, and IE 594 from Salibabu, Talaud Islands. Whereas subcluster $\mathrm{L}$ and $\mathrm{M}$ consisted of accessions from different sites, but genetically was similar. Subcluster L showed cluster randomly between accessions from Salibabu (IE 587 and IE 588) and Karakelang, Talaud Islands (IE 586). Sub cluster M also showed cluster randomly between accessions from Sangihe (11 accessions) and Karakelang, Talaud Islands (IE 577). According to Santosa et al. (2012), this phenomenon is probably that clonal propagation might common in past time.

\section{Genetic diversity analysis}

The knowledge about the genetic diversity of crop is essential in genetic improvement programs (Wu et al. 2014), can assist the development of efficient germplasmmanagement and utilization strategies (Kaewpongumpai et al. 2016) and the keys of success of breeding programs (Kumar et al. 2017). Several parameters are used for analyzing the genetic diversity, that is the mean of the observed number of alleles $(\mathrm{Na})$, the mean of an effective number of alleles $(\mathrm{Ne})$, the percentage of polymorphic loci (PPL), Nei's gene diversity (H) and Shannon's Information index (I).

The genetic diversity from each population is shown in Table 4. Amongst four populations of daluga were studied, Siau Island population has the highest level of genetic variation with mean values of $\mathrm{Na}=1.9375 \pm 0.2436, \mathrm{Ne}=$ $1.6409 \pm 0.3255, \mathrm{PPL}=93.75 \%, \mathrm{H}=0.3614 \pm 0.1516$ and $\mathrm{I}=0.5299 \pm 0.1978$. Meanwhile, Salibabu, Talaud Island population has the lowest level of genetic variation with mean values of $\mathrm{Na}=1.5125 \pm 0.5030, \mathrm{Ne}=1.3075 \pm$ $0.3723, \mathrm{PPL}=51.25 \%, \mathrm{H}=0.1800 \pm 0.1989$ and $\mathrm{I}=$ $0.2700 \pm 0.2855$.

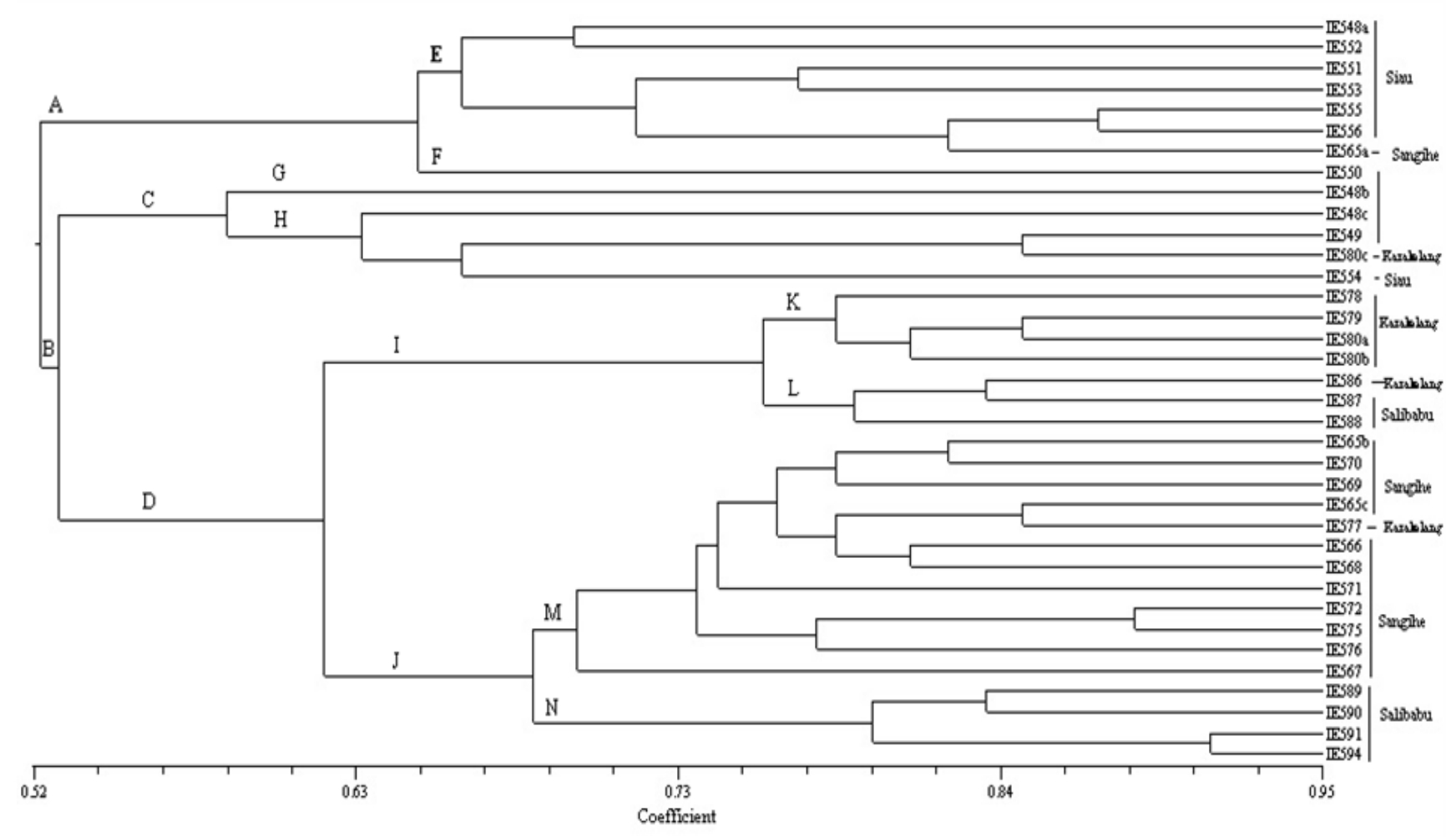

Figure 3. Dendrogram of genetic similarity among 36 accessions of daluga based on UPGMA algorithm 
Table 4. Genetic diversity of four populations of daluga

\begin{tabular}{lcccccc}
\hline \multicolumn{1}{c}{ Population } & $\begin{array}{c}\text { Sample } \\
\text { size }\end{array}$ & Na & Ne & $\begin{array}{c}\text { Percentage of } \\
\text { Polymorphic Loci (PPL) }\end{array}$ & H & I \\
\hline Siau & 11 & $1.9375 \pm 0.2436$ & $1.6409 \pm 0.3255$ & 93.75 & $0.3614 \pm 0.1516$ & $0.5299 \pm 0.1978$ \\
Sangihe & 12 & $1.800 \pm 0.4025$ & $1.4792 \pm 0.3761$ & 80.00 & $0.2766 \pm 0.1911$ & $0.4130 \pm 0.2620$ \\
Karakelang, Talaud & 7 & $1.7625 \pm 0.4282$ & $1.4255 \pm 0.3727$ & 76.25 & $0.2500 \pm 0.1901$ & $0.3785 \pm 0.2618$ \\
Salibabu, Talaud & 6 & $1.5125 \pm 0.5030$ & $1.3075 \pm 0.3723$ & 51.25 & $0.1800 \pm 0.1989$ & $0.2700 \pm 0.2855$ \\
\hline
\end{tabular}

Notes: Na : Mean of the observed number of alleles; Ne: Mean of the effective number of alleles (Kimura and Crow 1964); PLP:

Percentage of Polymorphic Loci; H: Nei's (1973) gene diversity; I: Shannon's Information index (Lewontin 1972)

Within most of the studied populations, a relatively high level of genetic diversity has detected (PPL values ranged from 51.25 to $93.75 \%, \mathrm{H}$ ranged from 0.1800 to 0.3614 , and I ranged from 0.2700 to 0.5299 ) compared to the results obtained for other tuber crop from the same family (Araceae), namely Amorphophallus konjac using AFLP with PPL values ranged from 29.3 to $67 \%, \mathrm{H}$ ranged from 0.066 to 0.202 , and I ranged from 0.113 to 0.313 (Pan et al. 2015).

The highest level of genetic variation on Siau population with mean values of $\mathrm{Na}=1.9375 \pm 0.2436, \mathrm{Ne}=$ $1.6409 \pm 0.3255, \mathrm{PPL}=93.75 \%, \mathrm{H}=0.3614 \pm 0.1516$ and $\mathrm{I}=0.5299 \pm 0.1978$ indicated that Siau Island is probably one of the center of origin of daluga in Indonesia. According to Vavilov (1951), the center of origin is a geographical area where a group of organisms, either domesticated or wild, first developed its distinctive properties. It is also considered as centers of diversity. This high level of genetic variation on Siau Island is probably caused by occurs out-crossing pollination more than selfpollination. The flowers of Cyrtosperma spp. are pollinated by insects. It is the host plant for the brown tussock moth, namely Olene mendosa (NParks Flora\&FaunaWeb 2013). According to Pan et al. (2015), the transfer of pollen by insect pollinators between different plants may increase the possibility of out-crossing and, subsequently, would increase the genetic diversity in the studied populations.

The genetic diversity of a plant species is determined by several factors, such as mating systems, life history, evolutionary history, geographic distribution range, and environmental factors (Loveless and Hamrick 1984; Hamrick and Godt 1990, 1996; Pan et al. 2015). The high levels of genetic diversity found in populations of daluga in this area study may be explained firstly by its mating systems. Although daluga is a clonal plant and reproduces asexually through tubers, it can also reproduce sexually by out-crossed seeds, similar with Amorphophallus variabilis (Santosa et al. 2012) and A. konjac (Pan et al. 2015).

The grouping of genetic diversity between four populations of daluga were analyzed using Nei's genetic distance (1978) with UPGMA methods (Figure 4). In general, daluga formed into two major groups. Group I consisted of population 4 (Salibabu, Talaud Islands) and group II included of population 2 (Sangihe Island) which are grouped itself and population 1 (Siau Island) and population 3 (Karakelang, Talaud Island) which are clustered into one group (Figure 3). This result indicated that Siau and Karakelang have the similar genetic properties.

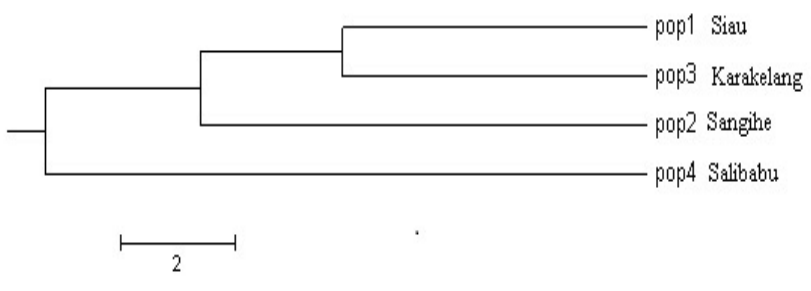

Figure 4. Dendrogram of four populations of daluga according to Nei's genetic distance (1978)

Table 5. Nei's genetic distance (Nei 1978) for four populations of daluga

\begin{tabular}{lcccc}
\hline Population & $\mathbf{1}$ & $\mathbf{2}$ & $\mathbf{3}$ & $\mathbf{4}$ \\
\hline 1 & $* * * *$ & & & \\
2 & 0.1663 & $* * * *$ & & \\
3 & 0.1059 & 0.1444 & $* * * *$ & \\
4 & 0.2787 & 0.1785 & 0.1704 & $* * * *$ \\
\hline
\end{tabular}

Notes: Population $1=$ Siau, $2=$ Sangihe, $3=$ Karakelang, Talud, 4 $=$ Salibabu, Talaud

\section{The genetic distance among populations}

The Nei's genetic distance (Nei 1978) for four populations of daluga performed in Table 5 . The highest genetic distance (0.2787) has occurred between population 1 (Siau Island) and population 4 (Salibabu, Talaud Island), meanwhile, the lowest genetic distance $(0.1059)$ was between population 1 (Siau Island) and population 3 (Karakelang, Talaud Island).

The Nei's genetic distance (Nei 1978) for four populations of daluga ranged from 0.1059 until 0.2787 . The highest genetic distance $(0.2787)$ has occurred between the population of Siau Island and the population of Salibabu, Talaud Islands. This value indicated that there is great barrier geography between Siau and Salibabu population. It's also interpreted that small possibility of these two populations derived from a common ancestor. On the contrary, the lowest genetic distance $(0.1059)$ has occurred between Siau and Karakelang which indicated that these two populations could have the same genetic background.

The results of current study concluded that SRAP molecular marker is a suitable approach to analyze the genetic variation of daluga in Siau, Sangihe, and Talaud 
(Karakelang and Salibabu) Islands. SRAP has been shown to be a quick, simple, economical, and reproducible method for identification and grouping of daluga accessions. The relatively high level of genetic diversity generated using SRAP marker was responsible for the large genetic variation on daluga. This genetic information can be used for baseline data for further research especially to improving the variation of daluga through plant breeding, so it produces the accession with higher genetic diversity. This result is very important for conservation of daluga in the future as an alternative food, particularly in small islands of Indonesia

\section{ACKNOWLEDGEMENTS}

The authors acknowledge gratefully to the all member of Molecular Laboratory, Botany Division, Research Center for Biology, Indonesian Institute of Sciences for the molecular work and also to Ministry of Research, Technology and Higher Education of the Republic of Indonesia for the financial support for field study and research funding. We would also like many thanks to Aira, Stacia with their big family and all the people in Siau, Sangihe and Talaud Island who help the first author during the fieldwork and also many thanks to Farid Rifaie who provide the map of sampling location. We want to thank the editors and the reviewers whose knowledgeable suggestions and comments improved this paper.

\section{REFERENCES}

Ahmad R, Potter D, Southwick SM. 2004. Genotyping of peach and nectarine cultivars with SSR and SRAP molecular markers. J Amer Soc Hort Sci 129 (2): 204-210.

Amar MH, Biswas MK, Zhang Z, Guo W. 2011. Exploitation of SSR, SRAP, and CAPS-SNP markers for genetic diversity of Citrus germplasm collection. Sci Horti 128: 220-227.

Aneja B, Yadav NR, Yadav RC, Kumar R. 2013. Sequence related amplified polymorphism (SRAP) analysis for genetic diversity and micronutrient content among gene pools in mungbean [Vigna radiata (L.) Wilczek]. Physiol Mol Biol Plants 19 (3): 399-407.

Ardiyani M, Sulistyaningsih LD, Esthi YN. 2014. Keragaman genetik berdasarkan marka Inter Simple Sequence Repeats pada Tacca leontopetaloides (L.) Kuntze. Berita Biologi 13 (1): 85-96.

Bhatt J, Kumar S, Patel S, Solanki R. 2017. Sequence-Related Amplified Polymorphism (SRAP) markers based genetic diversity analysis of cumin genotypes. Annals of Agrarian Science 15: 434-438.

Dingan CA, Burlingame BA, Arthur JM, Quigley RJ, Milligan GC. 1994 The Pacific Island Food Composition Table. South Pacific Commission

Doyle JJ, Doyle JL. 1987. A rapid DNA isolation procedure for small quantities of fresh leaf tissue. Pythochem Bull 19: 11-15.

Erlinawati I, Abinawanto, Salamah A, Rugayah. 2018. Morphological variations in wild population of tuber crop Cyrtosperma merkusi (Hassk.) Schott (Araceae) in Siau, Sangihe and Talaud Islands, North of Sulawesi. Proceeding of The 7th International Symposium for Sustainable Humanosphere Bogor.

Evangelio FA. 1996. Cyrtosperma merkusii (Hassk.) Schott. In: Flach M, Rumawas F (eds) Plant Resources of South-East Asia, vol 9, Plants Yielding Non-Seed Carbohydrates. Prosea Foundation, Bogor
Feng F, Chen M, Zhang D, Sui X, Han S. 2009. Application of SRAP in the genetic diversity of Pinus koraiensis of different provenans. Afr J Biotechnol 8: 1000-1008.

Hamrick JL, Godt MJW. 1990. Allozyme diversity in plant species. In: Plant population genetics, breeding and genetic resources. Brown AHD, Clegg MT, Kahler AL, Weir BS (eds). Sinauer Associates Inc., Sunderland, Massachusetts. p43-63.

Hamrick JL, Godt MJW. 1996. Effects of life history traits on genetic diversity in plant species. Philos. Trans. R. Soc. B-Biol. Sci. 351: 1291-1298.

NParks Flora\&FaunaWeb. 2013. Cyrtosperma merkusii (Hassk.) Schott. National Parks Board, Singapore. https: //florafaunaweb.nparks.gov.sg/special-pages/plantdetail.aspx?id=5909. Accessed August 31, 2018.

Julianti E, Simbala HEI, Koneri R, Palealu J. 2012. Kajian morfologi daluga (C. merkusii (Hassk.) Schott) di Kabupaten Kepulauan Sangihe, Sulawesi Utara. Jurnal Bioslogos 2 (2): 69-78.

Julianti E, Pinaria A, Lengkong EF, Kolondam BJ. 2015. DNA barcoding tanaman daluga (Cyrtosperma spp.) dari Kepulauan Sangihe berdasarkan gen matK. Jurnal Bioslogos 5 (2): 46-54. [Indonesian]

Kaewpongumpai S, Poeaim S, Vanijajiva O. 2016. Sequence-Related Amplified Polymorphism (SRAP) analysis for studying genetic characterization of Bouea macrophylla. Biodiversitas 17 (1): 539-543.

Kimura M, Crow JF. 1964. The number of alleles that can be maintaned in a finite population. Genetics 49 (4): 725-738.

Kumar S, Parekh MJ, Fougat RS, Parel SK. 2017. Assessment of genetic diversity among okra genotypes using SSR markers. J Plant Biochem Biotech 26: 172-178.

Li G, Quiros CF. 2001. Sequence Related Amplified Polymorphism (SRAP) a new marker system based on a simple per reaction: Its applications to mapping and gen tagging in Brassica. Theor Appl Genet 103: 455-461.

Li G, McVetty PBE, Quiros CF. 2013. SRAP molecular marker technology in plant science. Plant Breed Lab Fields. DOI: $10.5772 / 54511$

Loveless MD, Hamrick JL. 1984. Ecological determinants of genetic structure in plant populations. Annu. Rev. Ecol. Syst. 15: 65-95.

Manner HI. 2011. Farm and forestry production and marketing profile for giant swamp taro (Cyrtosperma chamissonis). In: Elevitch CR (ed) Speciality crops for Pacific Island agroforestry. Permanent Agriculture Resources (PAR), Holualoa.

Nei M. 1973. Analysis of gene diversity in subdivided populations. Proc Nat Acad Sci USA 70 (12): 3321-3323.

Nei M. 1978. Estimation of average heterozygosity and genetic distance from a small number of individuals. Genetics 89 (3): 583-590.

Pan C, Gichira AW, Chen JM. 2015. Genetic variation in wild populations of the tuber crop Amorphophallus konjac (Araceae) in central China as revealed by AFLP markers. Genet Mol Res 14 (4): 18753-18763.

Plucknett DL. 1977. Giant swamp taro, a little-known Asian-Pacific food crop. In: J. Cock, R. MacIntyre, M. Graham (eds). Proceedings of the 4th symposium of the International Society for Tropical Root Crops (Columbia, 1976), IDRC-080e. International Development Research Centre, Ottawa.

Rao, S., M. Taylor, A. Jokhan. 2014. A descriptor list for giant swamp taro (Cyrtosperma merkusii) and its cultivars in the federated states of Micronesia. Telopea 16: 95-117.

Rohlf FJ. 2005. NTSYS-pc: Numerical Taxonomy and Multivariate Analysis System Version 2.2. Exeter Software. Setauket, New York.

Santosa E, Sugiyama N, Kawabata S, Hikosaka S. 2012. Genetic variations of Amorphophallus variabilis Blume (Araceae) in Java using AFLP. J Agron Indonesia 40: 62-68.

Vavilov NI. 1951. The origin, variation, immunity and breeding of cultivated plants (translated by K Start Chester). Chronica Botanica $13(1 / 6): 364$

Wu ZG, Li XX, Lin XC, Jiang W, Tao ZM, Mantra N, Fan CY, Bao XQ. 2014. Genetic diversity analysis of yams (Dioscorea spp.) cultivated in China using ISSR and SRAP markers. Genet Resour Crop Evol 61: 639-650. 